\title{
FORESTRY SHOULD BEGIN WITH THE FOREST ${ }^{1}$ By A. C. CiIne Harvard Forest
}

Reforestation by planting has received a great deal of attention in the press and at conservation meetings.

There are many thousands of square miles of sub-marginal land that requires planting, but are we preserving the woodland that we have and managing it efficiently. A survey of any farming section will show that woodlots are disappearing as a result of pasturing and that in many cases no attempt is being made to improve the woods by clearings and improvement cuttings. This work does not make the appeal that changing a bare field to a green forest in a decade by planting does but it is surer and will pay larger dividends.

There is need for education and foresters should give the lead. It is easy to follow the line of least resistance and enthusiasm for planting has been followed by many.

$\mathrm{A}$ $S$ YOU MAY have guessed from the title, my purpose in this article is to put in a word for what might be termed wild land forestry, as contrasted with the orderly row planting of baby conifers on abandoned fields or pastures. It is not a question of one versus the other - both are needed, in their proper place. Rather, it is a matter of the latter having been in the spot light so long that many laymen now think of forestry and tree planting as being synonymous, while the former still remains in the distant background. I believe that, in their failure to take advantage of the natural stocking which is commonly present on cutover lands in this region, many woodland owners are overlooking an opportunity to develop a very satisfactory investment in timber growing. But let us consider first the subject of forest planting.

The person who would start a forest by planting takes it upon himself to initiate a community of living organisms which is expected to grow and remain healthy for a half century or more, to draw from the particular environment under which it chances to be established all of the essential needs for its development as a crop which eventually will bring a profit to the owner. And yet most of us go about the purchase of forest planting stock and its setting out with all the optimism of a youth starting his first bed of lettuce and radishes. The reasons for this are not hard to find. To begin with, the methods used in agriculture for centuries past have become so firmly imbedded in our minds - clearing the land, planting and harvesting, and repeating the process next season - that we think of growing trees in the same way as we would growing corn or potatoes, the essential difference being the length of time till maturity. We lose sight of the fact that agricultural crops are given a great deal of care and protection during the growing season - cultivating, fertilizing, spraying, and so forth — which cannot possibly be given tree crops except at a loss.

Really, the chances of an artificial stand keeping safe and healthy, and developing into a profitable crop, are much smaller than in the case of a stand which originates naturally and is composed of native tree stock growing on a soil to which it is inherently adapted. For proof of this we have only to look at the outcome of earlier plantings. White pine plantations, which were set

\footnotetext{
1Reprinted from "Connecticut Woodlands," VI: 2, May, 1941.
} 


\section{FORESTRY SHOULD BEGIN WITH THE FOREST-CLINE 153}

out so enthusiastically years ago on hundreds of old fields and pastures, have been so severely damaged by the white pine weevil that they are now little better than rows of large bushes. Scotch pine, a species brought over from Europe, has seldom given us other than "scrub" trees. Red pine may have had fewer troubles, but there is no assurance that the attacks by sawflies, experienc. ed in several different localities in recent years, may not become more serious, not to mention the damage already caused by the European pine shoot moth and the tympanis canker. Norway spruce, another introduced species, is sub. ject to attack by the white pine weevil, and European larch has sustained con. siderable damage from porcupines and squirrels. The very fact that these artificial stands are not fitted to the site, that they are not adjusted to the environment - and thus are not healthy and vigorous throughout life - makes them easy prey for all sorts of insect and animal pests and fungus diseases. There is little we can do about this at present. In the absence of adequate knowledge of the growth habits and requirements of the various tree species and of what constitutes the essentials of a healthy forest environment, especially as regards the forest soil, it is bound to be largely by chance that an artificial stand is suited to the site and properly constituted within itself, as to species composition, distribution of trees, and other factors.

Foresters have recognized the weakness of the foundation upon which forestry has been developing, but the tree planting urge, at least among those sentimentally inclined, is so firmly established, and the support of tree planting by the great mass of urban residents so much in evidence, that most for. esters have despaired of doing anything about it.

Let us admit that there is a great need for tree planting over and above any considerations of timber production, but at the same time. let us realize that the elements which make for satisfaction in the eyes of the sentimentalist, or of the city dweller who looks upon the forest solely as a place for recreation are far removed from those which will satisfy the person who would invest money in the growing of trees as a business enterprise.

By way of contrast with artificial tree crops, let us consider young stands of volunteer origin, self-seeded on cutover land. That there are millions of acres of naturally stocked woodlands in southern New England no one can deny; and it is on this large area of wild land, which nature has restocked in her own way with trees, shrubs, ground plants and animal life, where forestry should begin, rather than on a worn out field or pasture which lacks $a_{1}$ forest soil and any cover for the protection of young trees. There is scarcely a young volunteer stand anywhere on cutover land which cannot be profitably improved by some kind of silvicultural treatment, unless the soil is very poor or the land burned over. Most needed among these at the present time is weeding, a cutting applied to sapling-size stands for the purpose of improving their composition (representation of the different species) and quality, by eliminating bad trees in favour of good ones.

Because of repeated clear cuttings for lumber or cordwood without regard for the ensuing stand, our forests have become choked with worthless and defective trees, like gardens which have never been weeded. Nothing could be more satisfying to a person interested in improving his forest than to spend his spare time, machette in hand, sorting out the crop trees from the weed trees, cutting this stem and leaving that, freeing a well-formed sapling of 
valuable species from suppression by a rank-growing stump sprout, or tree of inferior species. Such a treatment is a delight to anyone who has taken the time to study the habits and characteristics of the different species of trees, who has a plan in mind for the development of his forest, and faith in the sound. ness of the plan. For a quarter to a half of what it ordinarily would cost to plant an open pasture, a woodland owner can completely weed a young wild stand. A competent workman can weed at least one acre per day on the average. The secret of covering a lot of ground in a short time lies in cutting just enough to accomplish the purpose. Numerous inferior trees which are below the crop trees in height, and others which are short-lived or not interfering with anything valuable, are left untouched.

In stands which already have passed the sapling stage there are other profitable treatments which may be applied, such as improvement cutting and thinning. The former is essentially the same as weeding, though the axe replaces the machette, and the inferior trees removed may be large enough to be useful for fuel-wood or fence posts. Even stands which are largely made up of hardwood stump sprouts (coppice) may be profitably improved by one who knows how to thin sprout clumps without the risk of decay entering the favored stems. A knowledge of the effect of thel different species' of trees on the fertility of the forest soil - principally through the activity of earthworms, which live on leaves - makes possible a choice between species which on other grounds might be equally valuable. And an understanding of the food habits of destructive insect pests, such as the gypsy moth and white pine weevil, will influence the choice of trees to cut and to leave, from the standpoint of crop security and reduced protection costs. Similarly, a knowledge of the conditions which minimize damage caused by forest tree diseases saves trouble and increases the profit on the crop. Indeed, the application of the most profitable and effective kind of weedings and improvement cuttings to young stands of natural origin demands a considerable fund of knowledge.

These are the sort of treatments which may be carried out advantageously over thousands of acres of land in southern New England now supporting young stands of natural origin, and which, if judiciously applied, will in my opinion produce results much more satisfying than we may hope for in the case of artificially planted stands. Apparently greater knowledge is required to improve a wild stand than to set out a plantation, but actually what in the latter case seems simple enough requires a knowledge which does not exist at the present time. Some foresters may be bold enough to suggest a tree planting plan for your abandoned field or pasture, but they do so with little assurance of what the outcome will be.

No, forestry is not simple; and forestry practices cannot be reduced to a few simple rules. But to the woodland owner who is thoroughly interested in the possibilities of forestry and would like to invest some time and money in something which can continue to grow in size and volume regardless of business depressions or threats of war, I say let him look first to his better stocked areas of young wild forests, for in them he will find the opportunity to get the greatest return for the least outlay. And to the foresters let it be said that, until the day comes when the people understand that forestry begins with the forest, and not necessarily with cutover or devastated land, we have failed to put forestry on a sound basis, either biologically or economically. 